\title{
The Enlightenment of foreign ESP English on the development of College English education in China
}

\author{
Li Lan \\ Humanities School, Wuhan Guanggu vocational college, Wuhan, China
}

Keywords: ESP English, College English education, development.

\begin{abstract}
ESP English teaching began in the last century in 60s, pay attention to professional education oriented English teaching activities of higher education with professional education as the foundation of English education, use ESP professional education has obvious advantages, based on the Enlightenment of foreign ESP English on China's College English education in-depth research, analysis of the foreign ESP English teaching, English education link of University of our country existing problems, and puts forward the feasible scheme of foreign ESP English education in College English teaching stage, aims to promote the teaching level of English Majors of our university to improve.
\end{abstract}

\section{Introduction}

With the trend of development of global integration of economy and culture, China's higher education has gradually to the internationalization development, College English education is the foundation of China's higher education teaching content, to improve the application level of college students and provide effective help for the future development of the students' occupation, but there are many problems that can not be ignored in in China's College English teaching, leading students in Higher Education after the English learning content can not do. The content of English teaching ESP English education professional use, professional learning and development of occupation education demands, pay attention to the targeted teaching content and teaching practice, the application of clear teaching objectives and teaching content combine to enhance students' professional skills and comprehensive quality, and promote students' occupation development higher level. To study the implication of ESP English Teaching in College English teaching, it is important to promote the comprehensive teaching of China's higher education level promotion[1].

\section{Foreign ESP English Teaching}

Foreign ESP English teaching according to the application purpose of the application and use of language environment, which is mainly divided into occupation English and academic English two class, occupation English is mainly used in various fields of production and business activities, the latter is more inclined to academic research, the scope of application of the more extensive application occupation. English is the first language, its role in the development of cultural exchange and social economy gradually, the professional education of higher education, the international community must fit the development needs, gradually improve their comprehensive professional teaching level, with international professional education docking, enhance the professional students in China in the international competition. Foreign demand for professional education in developed countries must learn English professional courses, ESP professional English teaching has been widely used in Japan, Thailand and other countries, in the international education exchanges have become more frequent under the condition of ESP professional English education is already in many institutions of higher education represent the general trend, also cater to student demands, to have some professional English learning based on students learning English curriculum, enhance the level of learning to students, the application of ESP English teaching not only can effectively enhance students' English learning level, plays an important role in promoting and 
enhance the level of learning and professional development for students[2].

ESP professional English mainly with obvious lexical features and grammatical features, while focusing on learning English teaching is the ESP analysis of the professional English vocabulary, and summarized the application of the method, the English vocabulary and grammar constitute the main content of ESP teaching, although professional grammar and vocabulary learning, also exist in the EST in the teaching of EGP, but its targeted and comprehensive English teaching is far less than ESP. ESP English Teaching in the basic vocabulary and grammar learning register on the discourse analysis theory for flexible application, the register study to discourse study, to analyze the level of understanding of professional language in discourse, there are also differences with different language application environment for English vocabulary and rhetoric methods, thus for.

The analysis and study of different discourse structures are of great significance for promoting the study and application level of specialized english. English language learning is the mastery of English skills, need to read and write four aspects to make the learners will learn English into self professional skills to enhance the process of English learning in listening and speaking, need to enhance the professional skills focus on reading skills in English listening and speaking occupation, and then pay more attention to academic English reading and writing skills. Learners of English learning skills, can independently carry on the structure and understanding of language environment, language meaning, and the lack of clear professional learning oriented thinking, it will lead to learning to realize the goal, thus starting from the practice of English education of College Students' interest in learning, learning needs, establish a clear learning goals, learning as the target to guide the direction of teaching activities, and help to promote the realization of teaching goal[3].

\section{The problems existing in our college English Education}

College English teachers' professional English education generally has low teaching efficiency, the main reasons are: first, teachers, teachers of higher education teaching system based on teaching English teachers for English teachers, and teachers often focus on professional learning, research and teaching ignored professional English, especially for science teachers are not good at English, relates to the field of education to the educational research and teaching activities is limited, the main reason for this phenomenon is that the current higher education professional teachers is the last century the education and training of teachers, and then the teachers' training has not reached consensus with the rest of the world, resulting in Teachers' professional level and the level of English is not Symmetry, which is difficult to carry out effective ESP Education under the present situation; second, higher education for professional English education in the education resources are limited, at present only a few top universities in practice and development of professional education, and many universities are still using ordinary college English teaching mode for English teaching is not deep enough it is difficult for students, after school education, realize the system of professional English learning.

Our country's college education and teaching system are routine tendency obviously, many schools of professional disciplines can be set up under the guidance of teaching outline, and subjects for other colleges and universities to imitate and learn from, and the lack of demand for learning and students' actual teaching needs consideration, teaching subjects and the teaching contents are lack of awareness of innovation, resulting in many schools are lack of attention for ESP English education. There are many schools did not realize that the teaching innovation is important for their sustainable development, blindly follow the trend of subject setting, but no comprehensive consideration on the bearing capacity of its educational resources, leading to their own educational resources and teaching level can not meet the actual needs of professional education, professional English education is more difficult to achieve, students only can the ordinary college English learning, learning content, lack of pertinence and practice, caused many students to reject the College English learning, students can do to apply their knowledge in the learning process, but also to enhance the student's professional level is restricted[4].

With the development and progress of society, gradually improve China's social and economic development and the development level of the humanities, for academic research and professional 
occupation talents rising demand, development of the construction field, need professional to developed countries advanced manufacturing technology have comprehensive understanding, and promote the development of construction industry China; the development of the trend of global economic integration, requires a large number of International Business English, legal English and other professional personnel; the medical and health service in China's reform and development has achieved significant results, but with the developed countries in the world in some areas there are still large differences in the medical level, the development of medical science also need to continue to communicate and learn actively with the world advanced medical technology, also need a large number of medical professionals; China's financial Industry started relatively late, the capital developed countries have many professional experience, it is worth our learning and reference, and so on. The real problem facing these social development needs the application of professional English as a communication means and carrier communication, language and academic exchanges in the continuous learning process, realize the related specialty in China's development and progress, higher education is an important foundation for the future development of professional education, professional in the field of industry, but also the talent pool the need for effective means of modern higher education, professional English teaching is the key factor to promote the development of related industries, but the current college English Teaching in higher education is difficult to meet the different needs of professional development.

At present, the Ministry of education on Higher Education English teaching consists of professional English teaching and English teaching, for English majors, the English majors tend to not enough refinement, while minor in second languages, but we can not choose professional English, encourage students to learn professional English prefer learning mode, the only measure the grade examination as the learning level, limiting the expansion of ESP English teaching and learning. For non English major students, many schools have English as a common course, many schools have no according to the actual needs of professional majors in English subject, partly because the English teachers' professional level is limited, while the other is university for professional education is lack of long-term strategic vision, the lack of social responsibility no, the ESP professional English education as teaching focus problem, limiting the expansion of the ESP teaching mode[5].

\section{The feasible scheme of foreign ESP English education in College English Teaching}

The need for Western ESP teaching theory in-depth study, to clear its significance for the development of their professional teaching play, and the teaching idea of deepening, according to their own teaching practice situation, realize the localization of ESP adjustment of English teaching, so that it can meet the needs of English Teaching in higher education China. First of all colleges and universities need to their professional characteristics comprehensive consideration, to analyze and study the form of higher education in the country, and strive to achieve the innovation of their professional education, and professional education with its own characteristics and advantages in education, establishing and perfecting the professional English teaching system, especially for the international community more closely connected with some professional. ESP English education is the key to improve the teaching level of English education and professional education.

The teacher is the basis of ESP English education, the universities need to pay more attention to the training of ESP teachers, through school-based training or training way to accelerate the construction of a number of ESP to carry out the education of English teachers, so that it can have the skills of English education, and targeted to English Teaching ability, enhance the knowledge structure and the vision of business English teachers, to improve the English teachers of ESP English education, encourage them to constantly improve themselves and enhance the modern English teaching level, improve the quality of teaching in English classroom. At the same time can also actively encourage college English teachers and professional teachers to carry out teaching cooperation projects, through the advantages of cooperation between teachers, more and more English teachers can master the professional knowledge of discipline, so that discipline teachers can grasp the professional knowledge of english. The teacher is the student professional learning leader, 
teachers establish for professional research and learning, diligently enterprising spirit of inquiry, students can also be under the guidance of teachers, improve themselves actively, make full use of spare time to improve themselves, and can reduce the students for ESP English learning difficulties to make it to at the same time, the importance of learning English in professional learning, professional development and internationalization as their professional development direction, professional learning and occupation development itself to the world advanced level standards, upgrade their professional level and learning english.

Colleges and universities to improve their teaching competence, need to strengthen their own teaching quality and education influence, so the college can ESP English education as the basis, construction of professional learning and ESP learning English mutual coordination, and jointly promote the study on architecture for ESP teaching resources investment, so that it can be achieved with the professional teaching, English teaching to the public the proportion of ESP increased, the teaching, the teaching of English class, ESP English learning achievements into professional learning evaluation system, improve the credit ratio, which is helpful to improve the students' degree of attention for the ESP learning english. A ESP model of English teaching abroad to copy, easily disconnected with teaching situations, so universities need to teaching according to their application needs, innovation and development of the teaching method, the teaching application can meet students' professional occupation and development needs, professional development and academic research in the field of future occupation the student's application base, build strong operability, teaching effectiveness is obvious China ESP English teaching[6].

\section{Conclusion}

The teaching of foreign ESP English Teaching in professional and English, has obvious advantages, the College English education should pay more attention to the application of ESP teaching, enhance the strength of professional English teachers themselves, increase the application of teaching resources, constructing perfect ESP English education and professional education teaching system, students can not only make have professional knowledge, professional English communication skills with internationalization, promote professional international development based on the application of personnel training.

\section{References}

[1]Li Z. The Enlightenment on Babel and Babel Fish: Popularizing English for Specific Purpose(ESP)and Propelling He'nan Regional Economic Development[J]. Science Education Article Collects, 2014.

[2]Li S. The Enlightenments from ESP Theory on English Teaching and Learning in Application-oriented College[J]. Journal of Hubei Radio \& Television University, 2010.

[3]Huang G Y, Sun A N. On the Enlightenment of ELF Environment for ESP Teaching in Independent Colleges[J]. Journal of Jilin Teachers Institute of Engineering \& Technology, 2015.

[4]Wang L J. The enlightenment of professional business English teaching based on ESP theories[J]. Journal of Xinyu University, 2012.

[5]Liu Y, Xian J, Zhong S. Researches into ESP teaching of HVTC and their enlightenment[J]. Journal of Shenzhen Institute of Information Technology, 2009.

[6]Hao X, Yin Z. College English Teaching Reform in China: An Orientation toward ESP[J]. 2015, 2(2). 